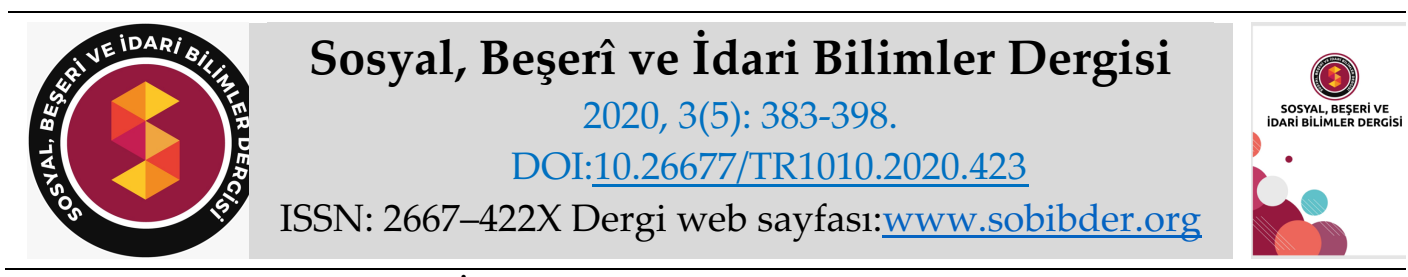

KAVRAMSAL MAKALESI

\title{
Algı Yönetimi Kavramı Çerçevesinde Geleneksel Medyada Gerçeklik Algısı
}

Öğr. Gör. Dr. Seçil UTMA, Aydın Adnan Menderes Üniversitesi, Atça MYO, Aydın, e-posta: secilut@hotmail.com

ORCID: https://orcid.org/0000-0002-5003-2137

Öz

Toplumların anlam dünyasını sistematik bir şekilde belirli bir ideoloji çerçevesinde düzenleyen medya; gerçeğin temsilinde belirleyici konumdadır. Medya araçlarından gelen iletiler bireylerin bilgi yapılarını şekillendirmekte, kişinin algı yapısını oluşturarak yaşam deneyimlerini sınırlandırmaktadır. Medya iletilerine maruz kalan birey, kendi yaşamıyla medya iletilerini karşılaştırmakta, bunun sonucunda da çoğunlukla kendi deneyimlerini terk ederek, medya deneyimlerini benimseme yoluna gitmektedir. Günümüzün karmaşıklaşan toplumlarında gerçeklik insanlara medya araçları tarafından sunulmakta, çevrelerinde olup bitenler hakkında bilgi sahibi olmaları sağlanmaktadır. Bireylerin kendi deneyimleri ile algıladığı gerçeklik ile medya gerçekliği arasındaki fark, toplumsal gerçeklik alanının yapılanmasını sağlamaktadır. Medya bireylerin gerçeklikle bağlantısını güçlü biçimde yapılandırırken, medya tüketicileri bu sayede hiç yaşamadığı/yaşayamayacağı deneyim alanlarına tanıklık etmekte, bunlara ilişkin anlamlar üretmektedir. Günümüzde zihinlerin inşasının kaynağı konumunda olan medya aracılığıyla, ekonomiden siyasete, kültürden sosyal ilişkilere kadar yeni algı kalıplarının oluşması sağlanmakta, bu sayede düşünme ve eylem biçimlerimiz, kültürel ve sosyal hayatımız bu çerçevede oluşmaktadır. Çalışmada; algı ve algı yönetimi kavramları üzerinde durularak, geleneksel medyada gerçeklik algısının inşası kuramsal olarak ele alınmıştır.

Anahtar Kelimeler: Medya, Gerçek, Algı, Medya Gerçekliği, Alg1 Yönetimi.

Makale Gönderme Tarihi: 12.02 .2020

Makale Kabul Tarihi: 02.05.2020

\section{Önerilen Atıf:}

Utma, S. (2020). Alg1 Yönetimi Kavramı Çerçevesinde Geleneksel Medyada Gerçeklik Algısı, Sosyal, Beşeri ve İdari Bilimler Dergisi, 3(5): 383-398.

(c) 2020 Sosyal, Beşerî ve İdari Bilimler Dergisi. 


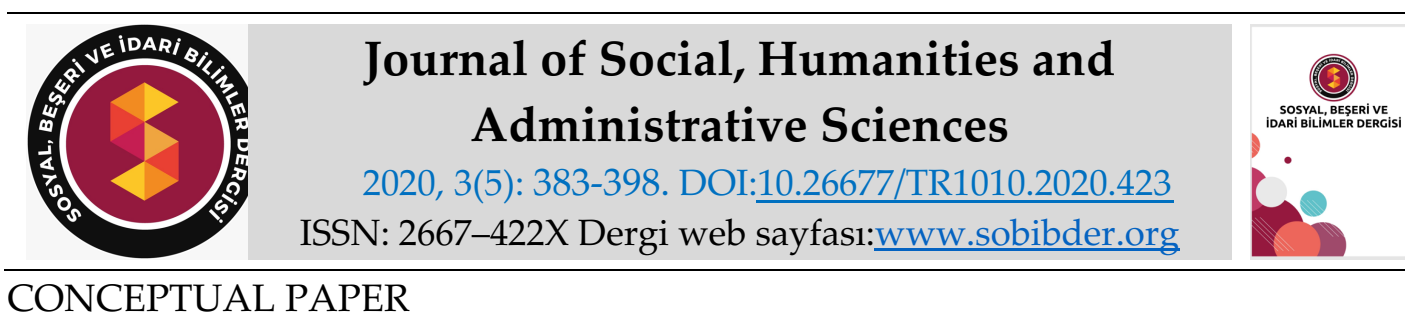

\title{
Reality Perception in Traditional Media within the Framework of Perception Management Concept
}

Dr. Seçil UTMA, Aydın Adnan Menderes University, Atça Vocational High School, Aydın, email: secilut@hotmail.com

ORCID: https://orcid.org/0000-0002-5003-2137

\begin{abstract}
The media that systematically organizes the world of meaning in the framework of a certain ideology; is decisive in the representation of truth. The messages coming from the media tools shape the individuals' knowledge structures, and create their perception structure and limit their life experiences. The individual exposed to media messages compares media messages with his own life, and as a result, he often abandons his own experiences and adopts media experiences. In today's complex societies, reality is presented to people by media and they are provided with information about what is happening around them. The difference between the reality that individuals perceive with their own experience and the reality of the media provides the structuring of the field of social reality. While the media strongly configures the connection of individuals with reality, the media consumers witness and experience the areas of experience they have never experienced. Today, through the media, which is the source of the construction of minds, new patterns of perception, from economy to politics, from culture to social relations, are created, so our ways of thinking and action, our cultural and social life are formed within this framework. In this study; considering the concepts of perception and perception management, the construction of the perception of reality in the traditional media has been handled theoretically
\end{abstract}

Keywords: Media, Truth, Perception, Media Reality, Perception Management.

Received: 12.02 .2020

Accepted: 02.05.2020

Suggested Citation:

Utma, S. (2020). Reality Perception in Traditional Media within the Framework of Perception Management Concept, Journal of Social, Humanities and Administrative Sciences, 3(5): 383-398.

(c) 2020 Sosyal, Beşerî ve İdari Bilimler Dergisi. 


\section{Gíriş}

Gerçeklik olgusunun en fazla tartışıldığı alanlardan biri olan medya, bir yandan hayatımızı kolaylaştırırken, öte yandan gerçek ve kurgu arasındaki uçurumun oluşmasına neden olmaktadır. İnsanları bir deneyim alanı ile buluşturan medya, onlara başka deneyim alanları sunmaktadır. Bireylerin kendi deneyimleri ile algıladığı gerçeklik ile medya gerçekliği arasındaki fark, toplumsal gerçeklik alanının yapılanmasını sağlamaktadır. Medya bireylerin gerçeklikle bağlantısını güçlü biçimde yapılandırmakta, medya tüketicileri bu sayede hiç yaşamadığı/yaşayamayacağı deneyim alanlarına tanıklık etmekte, bunlara ilişkin anlamlar üreterek toplumsal gerçekliğin inşasına katkı sunmaktadır. Medya aracılığıyla kitlelere kurgulanarak ve şekil değiştirerek ulaştırılan bilgi, gerçeklik olmaktan çıkmakta, bu yeni gerçekliğin hakikat ile bir ilgisi bulunmamakta, dezenformasyon halini almaktadır. Amerikalı siyasetçi Henry Kissinger'in de (2016: 67) belirttiği gibi, "Bir şeyin gerçek olması pek o kadar önemli değildir; fakat gerçek olarak algılanması çok önemlidir".

Teknolojik imkanların gelişmesi ve enformasyonun hızlı aktarımı sayesinde yeni bir görünüm kazanan alg1 yönetimi; insanlık tarihinin her döneminde var olmuştur. Bireyin zorunlu ya da kendi rızasıyla ikna edilerek, algılarının manipüle edilmesini amaçlayan algı yönetimi sayesinde, bireyleri herhangi bir konuda yönlendirmek mümkün olabilmektedir. İletişim teknolojilerinin günlük hayat pratiklerimiz içerisinde yerinin artması ile birlikte, bireylerin algılarını şekillendirmede kitle iletişim araçları önemli rol oynamaya başlamıştır. Sosyal medya ortamlarında bilgiye erişimin zaman ve uzamdan bağımsız bir şekilde hızlı ve ucuz hale gelmesi, etkileşimli iletişime olanak sunması, algı yönetimi açısından bu araçların önem kazanmasına yol açmıştır. Sosyal medya platformlarında nesnel gerçeklikten koparılan bilgi, yeniden kurgulanarak kullanıcılara ulaştırılmaktadır. Sanal alemde bilgi bombardımanı altında binlerce bilgi arasından en doğruyu seçmek giderek zorlaşmakta, tüketim metası haline getirilen bilgi; medyanın ideolojisi ile özdeş hale gelmektedir.

Kitle iletişim araçları aracılığıyla kendisine ulaşan iletileri algılayan birey medyanın yönlendirdiği gerçeklik illüzyonu içerisinde yaşamaktadır. Marcuse'un dediği gibi artık gerçeğe ilişkin düşünmemiz medyanın tanımladığı kavramlara bağlıdır (Koç, 2018: 12). Medya iletilerine maruz kalan bireyler Baudrilliard'ın (2005: 56) ifade ettiği gibi, kurgulanmış bir gerçeğin içinde yaşamaya başlayan sessiz yığınlar haline gelmekte, kurgulanan gerçek artık hakikatin yerini almaya başlamaktadır.

\section{ALGILAMA VE ALGI YÖNETIMİ}

Birey, çevresindeki uyarıcılar tarafından kendisine ulaşan sinyalleri duyu organları aracıllı̆̆ıyla algılamakta; geçmiş deneyimler, psikolojik durum ve içinde bulunulan kültürel yap1 çerçevesinde anlamlandırma yoluna gitmektedir. İletişim olgusunun önem kazandığı bu süreç sayesinde kişinin kendi dışında var olan dış dünyayı algılaması mümkün olmaktadır (Bakan ve Kefe, 2012: 20). İletişimin gerçekleşmesinde algılama önemli rol oynamakta, bireysel ve sosyal yaşamda dış dünyayla etkileşimin kurulmasına aracılık etmektedir. Kitle iletişim araçları, enformasyonun bireylere iletilmesinde önemli rol oynamaktadır.

Algı; kişinin çevresindeki nesneleri, olayları, ilişkileri duyu organları yoluyla anlamlandırarak, belli bir davranışı ortaya koyması sürecidir (İnceoğlu, 2011: 86). Bir başka yoruma göre ise algı, beynin çeşitli duyulardan gelen bilgi karmaşası içinden anlamlı örüntüler yorumlamasıdır (Morris, 2002: 121). Erol Mutlu ise (2012: 16) algıyı şu şekilde tanımlamaktadır: "Alg1; duyularla algılanan, beyin tarafından işlenen, bellekte depolanan ve fiziksel veya zihinsel bir tepki biçimi üreten enformasyondur. İnsanın çevresindeki uyaranların ya da olayların ayırımında olması ve 
onları yorumlaması sürecidir". Buna göre diş çevreden gelen uyarıcıların duyu organlarımız üzerinde bıraktığı etki 'duyu'; oluşan bu etkinin zihnimizde oluşturduğu şekle verilen anlam 'algı' olarak tanımlanmaktadır. Algıların alınma süreci ise algılamadır. Buna göre algı yönetimi algıdan başlayan, algılama ile devam eden bir süreci içermektedir (Türk, 2014: 15).

Algı; Tutar'ın (1988: 77) ifadesiyle, iç ya da dış çevreden gelen uyarıcıları bireyin duyu organları yoluyla ya da hisleriyle almasıyla başlayan ve bu uyarıcıların farkına varılmasını, tanınmasını, idrak edilmesini ve tanımlanmasını sağlayan fiziksel, nörolojik ve bilişsel süreçlerin tamamıdır. Çevredeki uyaran örüntülerin organizasyonu ve yorumlanması sürecidir. Kısaca bireyin dış dünyayı, çevresinde olup bitenleri anlamlandırma sürecidir. Bireyler geçmiş yaşantılarının da etkisiyle, yeni edindiği enformasyondan belirli seçmeler yaparak algılama işlemini başlatmakta, bu süreçte istek ve ihtiyaçlarımız belirleyici olmaktadır. İnsan algıları; bireyin değerleri, inançları ve içinde yaşadığı toplumsal kültür çerçevesinde şekillenmektedir.

Alg1 yönetimi kavramı ise ilk defa Amerika Birleşik Devletleri Savunma Bakanlığı tarafından tanımlanmıştır. Her ne kadar 'algı ve algılama', psikolojinin temel kavramları olarak pek çok bilimsel çalışmada ele alınsa da 'algıyı yönetmek', ilk kez ABD siyasi kararlarının ülkede ve tüm dünya kamuoyunda benimsenmesi için kullanılan bir yöntem olarak ortaya atılmıştır (Saydam, 2014:78). Algı yönetiminin özünü “ikna ve inandırma faaliyetleri” oluşturmaktadır. Bu çerçevede tarih boyunca gerek fert bazında gerekse de kurumsal temelde hedef kitleleri etkilemek için alg1 yönetim metotlarının kullanıldığı görülmektedir (Öksüz, 2013). ABD Savunma Bakanlığı'ndan yapılan tanıma göre algı yönetimi, "Kitlelerin duygu, düşünce, amaç, mantık, istihbarat sistemleri ve liderlerini etkileyerek, seçili bilgilerin yayılması ve/ veya durdurulması; bunun sonucunda hedef davranış ve düşüncelerinin hedefleyenin istekleri doğrultusunda yönlendirilmesidir" (http://enclopedia.thefreedictionary.com).

Garfield'e (2002: 33) göre algı yönetimi; etkileşime dayalı bir iletişim süreci olup, mesajların hedef kitlenin algı düzeyine uygun olarak biçimlendirilmesi ve bu suretle hedef kitlede istenilen tutum ve davranış değişikliğinin oluşturulması sürecidir. Alg1 yönetiminin başarısında gerçeklere dayanmak, farklılaşmak, tekrar, görsellik, duygulara hitap etmek, hedef kitlerinin değerleriyle ve beklentilerine yanıt vermek gibi birçok öğe önemli rol oynamaktadır (Özer, 2012:175).

Algı yönetimi genel olarak dört aşamadan oluşmaktadır: Hedef kitlenin dikkatinin çekilmesi, hedef kitlenin dikkatini kontrol altında tutmak için benzer bilgilerin sunulması ve paylaşılması, sunulan bilginin hedef kitlenin algılarıla tutarlı hale getirilmesi, bilginin ayn pozisyonda kalması için iletişim kaynaklarında tekrar edilmesidir (Callamari ve Reveron, 2003: 15). Kitlelerin hislerini, duygu ve düşüncelerini etki altına almak amacıyla yürütülen çabalar, algılama yönetimi olarak adlandırılmaktadır (Saydam, 2012:7).

Le Bon'un (2014:123) belirttiği üzere 'Tekrar, İddia ve Yayılma' kitleler üzerinde algılama sürecinde önemli rol oynamaktadır: "Sade bir içeriğe sahip anlaşılır bir iddia, kitlelerin ruhuna bir fikri yerleştirmek için en etkili araçtır. İddianın etkili olabilmesi için ise mümkün olduğu kadar aynı kelimelerle tekrarı önemlidir. İddia olunan şey, tekrar edilmek suretiyle ispat edilmiş bir hakikat gibi kabul olunarak zihinlere yerleşmektedir. Nitekim böyle bir durumda iddiaların kimin tarafından ortaya atıldığı unutulacak ve tekrarlanan mesajlara inanılacaktır".

Teknolojik imkanların gelişmesi ve enformasyonun hızlı aktarımı sayesinde yeni bir görünüm kazanan alg1 yönetimi; insanlık tarihinin her döneminde var olmuştur. Bireyin zorunlu ya da kendi rızasıyla ikna edilerek, algılarının manipüle edilmesini amaçlayan algı yönetimi sayesinde, bireyleri herhangi bir konuda yönlendirmek mümkün olabilmektedir. Sosyal medya ortamlarında bilgiye erişimin zaman ve uzamdan bağımsız bir şekilde hızlı ve ucuz hale gelmesi, etkileşimli iletişime olanak sunması, algı yönetimi açısından bu araçların önem kazanmasına yol açmıştır. 
Walter Lippman'a göre algı ile gerçeklik arasındaki uçurum modern dünya ile daha da genişleyerek, sosyal, siyasal ve ekonomik hayatın içerisinde yaşanan karmaşıklık, iletişim araçlarının (özellikle sosyal medya) zihnimizdeki imgeleri değiştirmesi ile hız kazanmıştır (Ünüvar, 2013). Bu süreçte sosyal medya yeni mecra olarak karşımıza çıkarken, algıların yönetimi dijital dünya üzerinden kurgulanmaya başlanmıştır. Gültekin'in de ifade ettiği gibi, “Bir savaş alanı olarak insan zihni, açık seçik bir bombardımana maruz bırakılmakta; kanma ile kandırma bu süreçte modern dünyanın en asli unsurları haline gelmektedir" (Gültekin, 2016: 11).

Alman sosyolog Ulrich Beck (1994) toplumların içerikten ziyade görüntüye ilgi gösterdiklerini, bu bağlamda bir mesajın görünüm, imaj ve sunumunun en az içeriği kadar önemli olduğunu söylemektedir (Aktaran: Lilleker, 2013: 33). Bu noktada sosyal medya, sahip olduğu özellikleri ile iletişimin sanal ortama taşınmasından çok öte bir misyona sahiptir. Uğurlu'nun (2015:301) da belirttiği gibi, "Sosyal medyanın bireylere sunmuş olduğu yazı, fotoğraf, ses, video ve her türlü bilgi ve belgeye ulaşım imkânları iletinin içeriğini ve tasarımını etkilemekte, bu sayede halkla ilişkiler, pazarlama, siyaset başta olmak üzere tüm alanlarda istenen algılara yönelik kampanya tasarımları oluşturulmaktadır. Sosyal medyanın multimedya yapısı ve hipermetinsellik özelliği sayesinde bireylerin simgesel, görsel, duygusal algilarının tümüne etki etme durumu söz konusu olmakta, böylelikle bireylerin algılarına çok yönlü ulaşma imkânı artmaktadır. Sosyal ağların görsel kültürle olan sıcak ilişkisi, görsel materyallerin teşhirine uygunluğu, paylaşıldığından kısa bir süre içerisinde kişilere yayılımı, enformasyonun imajlarla donatılıp dikkat çekicilik sağlamasını beraberinde getirmektedir".

İletilerin kitlere ulaştırılması sürecinde bireylerin tutum ve algılarının şekillenmesinde medyada kullanılan "çerçeveler" önemli rol oynamaktadır. Çerçeveler, "sorunları tanıyan, değerlendiren ve reçete eden iletişim araçlarıdır "(Entman, 1993: 51). Lilleker'in (2013:111) ifadesiyle, "toplumsal meseleleri düzenleyici fikirler ya da temalar olarak anlamayı kolaylaştırmak ve zenginleştirmek için tasarlanan bilişsel kısa yollardır". Bu etiketler, karşı tarafta yaratılmak istenen algının oluşma sürecinden rızanın tesisine kadar ki süreçte algı yönetene oldukça elverişli bir ortam sunmaktadır (Uğurlu, 2015: 304).

Günümüzde zihinlerin inşasının kaynağı konumunda olan medya aracılığıyla, ekonomiden siyasete, kültürden sosyal ilişkilere kadar yeni algı kalıplarının oluşması sağlanmakta, bu sayede düşünme ve eylem biçimlerimiz, kültürel ve sosyal hayatımız bu çerçevede oluşmaktadır (Yeniçıktı, 2014: 265). Algı yönetimi ile grupların tutum, davranış ve duyguları algı yöneticileri tarafından şekillendirilmekte; siyasi iktidarlar uygulamalarının meşruiyetini sağlamak, kurumlar ve fertler toplum nezdinde itibarlarını yükselmek gayesiyle birtakım psikolojik teknikleri kullanma yoluna gitmektedir.

Yoğun bilgi bombardımanı altında hangi enformasyonun doğru hangisinin yanlış olduğunun bilinmemesi, bireylerin algılarının şekillenmesinde belirleyici olmaktadır. Gültekin'in (2016: 65) de ifade ettiği gibi, “Bütünden koparılmış bilgi, sadece eksik bilgilenmemiz anlamına gelmez; aynı zamanda düşünce, duygu, davranış ve tutumların yanlış şekillenmesine neden olur. Bütünü görmek/görebilmek gün geçtikçe zorlaşmakta ve insanlar mikro dünyalar içerisine hapsedilmektedir; resmin tamamını göremeyenler manipülatörlerin oyununa gelmektedir. Modern dünyanın bu parçalı yapısı dijital çağ ile yakından ilgilidir. Bilgideki yüksek artış insanların kontrolünden çıkmakta ve böylece kimse ne olup bittiğini anlayamamaktadır. $\mathrm{O}$ yüzden bugün bilgi parçacıklarının sunumu ile gerçeğin büyük bir kısmı gizlenmekte ve bu da alg1 yönetmenleri ile manipülatörlerin işine gelmektedir".

Bireyleri manipüle ederek, algılarının yönlendirilmesi açısından bilimsel veriler büyük önem taşımaktadır. Günümüzün modern insanı açısından bilimin sahip olduğu kesinlik, algı yöneticileri için referans oluşturmaktadır. Teknolojik gelişmeler neticesinde artık bilimin 
yanlışlanabilirliği en temel olgu olarak görülse de halen kitlelerin zihnindeki karşılığından dolayı bilimsel verilere dayanarak toplumsal algıların inşası mümkün olabilmektedir (Gültekin, 2016:179).

\section{GERÇEKLİK VE MEDYADA GERÇEKLİK ALGISININ İNŞASI}

Gerçeklik, düşünülen, tasarımlanan ve imgelenenlerin aksine, gerçekte var olan ve varlığ algılamadan bağımsız olan olgulardır. Gerçek veya gerçeklik bilinçten, düşünceden ve kurgulanmış olandan bağımsız olarak var olmaktadır (Akarsu,1984:83). Gerçeklik, algılamanın tersine zihinsel bir ürün olmamakta, gerçeğin zihin üzerindeki izdüşümü olarak görülmektedir. Zihinsel süreçlerden bağımsız gerçekten bir var olma durumunu tanımlayan gerçeklik; nesnel ve objektif bir realiteyi ifade etmektedir. Birey gerçeklik denen olguyu ya birinci elden yaptığ 1 gözlemler yani yaşanmışlıkları sonucu ya da anlatılar veya medya kanalıyla kendisine ulaşan enformasyon çerçevesinde algılamaktadır.

Bireyin algıları her zaman gerçeği yansıtmamakta; kişinin eğitimi, deneyimleri, inançları ve kültürü algıların oluşmasında belirleyici olmaktadır. Uyaranın aynı olmasına karşın, bireylerin algılarının farklı olması, algı ile gerçek arasındaki farkı ortaya koymaktadır.

Gerçeklik algısı uygarlık tarihinde birçok filozofun tartıştığı konular arasında öncelikli olarak yer almıştır. Örneğin Antik Çağ filozoflarından Platon, gerçeği doğrudan görmediğimizi, onu dolaylı bir şekilde algilayabildiğimizi belirtmektedir. Çokça bilinen körlerin fil tarifi hikayesi bu duruma örnek teşkil etmektedir. Filin bacağını tutan kişi geçmiş deneyimlerinin de etkisiyle filin bacağını bir sütuna benzeterek, onunla özdeşleştirir. Bu tanıma itiraz eden diğerleri, kendi deneyimleri çerçevesinde fili tarif etmişlerdir.

Televizyondaki gerçeklik sorununu Platon'un "idealar evreni" kavramıla birlikte ele alan Morresi (2003: 15), televizyon izleyicisinin ekranda izlediği şeyi, Platon'un mağarasının günümüzdeki versiyonuna benzetmektedir. Ona göre, günümüz kitle iletişim araçları yarattıkları kurgulanmış gerçekliklerle kullanıcılarına ulaşmaktadır.

Algı ile gerçeklik arasındaki uçurum gelişen teknoloji ile birlikte daha da genişlemiş, kitle iletişim araçları algıların şekillenmesi noktasında belirleyici duruma gelmiştir. Lippman'ın (1998) da ifade ettiği gibi, kitlelere sunulan imgeler bir çeşit sanal gerçeklik yaratmakta ve bireylerin algılarının oluşmasında etkili olmaktadır. Gerçek, toplumsal yaşam içerisinde çok kritik bir önemi olan neden-sonuç ilişkisinin kültürel anlamda edinilen deneyimlerle kurulduğu bir alandır. Bireyin deneyimlerinin sonucunda geliştirdiği bilişsel şemaya uygun olan şeyler, ona göre gerçektir.

Toplumsal gerçeklik, yeryüzünde olup bitenlere ilişkin insanların ortaklaşa gerçekleştirdiği eylemler ile bunlara dair bütün düşünsel ve zihinsel etkinliklerin oluşturduğu gerçekliktir. Bu gerçekliğin oluşumunda medya, hem insanların fiilen içinde yaşadıkları toplumsal- tarihsel ortamlardan, hem de bunların dışındaki deneyimleri dolayımlayarak rol oynamaktadır.

Kendi yaşam alanlarımızın dışındaki dünyayı tanımamızı sağlayan en önemli araçlardan biri olan medya, bireylerin dış çevreyi algılamalarını, onun oluşturduğu gerçeklik perspektifinden olayların anlamlandırılmasını sağlamaktadır. Demokrasilerde yasama, yürütme ve yargıdan sonra "dördüncü güç" olarak nitelendirilen medya, elinde bulundurduğu güç sayesinde kitleleri harekete geçirerek, istenilen konularda tutum ve davranış değişikliği oluşturmakta, halkı asıl dertlerinden uzaklaştırarak onlara "sahte ve sanal" bir dünya sunarak, psikolojik bir silah olarak işlev görmektedir. Gezgin'in (2002: 36) de ifade ettiği gibi “Günümüzde medya; hedef kitlesinin yetiştirilmesinde, kültürel aktarımında, sorunlara cevap bulunmasında, herhangi bir konuda 
tutum geliştirilmesinde veya davranışta bulunulmasında, karar vermesinde büyük paya sahiptir".

Medya aracılığıyla kitlelere kurgulanarak ve şekil değiştirerek ulaştırılan bilgi, gerçeklik olmaktan çıkmakta, bu yeni gerçekliğin hakikat ile bir ilgisi bulunmamakta, dezenformasyon halini almaktadır. Kars"a (2010:176) göre "Medya alımlayıcıları; kültürel deneyimlerden yola çıkarak kendine gerçeklik kategorileri yaratan bireysel/toplumsal gerçekliğin sorgulanmasına yönelik yargıların büyük birçoğunu başkalarının medya ile olan deneyimine dayandırmakta ya da kendi içsel dünyasının gerçekliği ile medyanın sunduğu gerçeklik arasında bocalayıp durmaktadır".

Gerçeklik olgusunun en fazla tartışıldığı alanlardan biri olan medya, bir yandan hayatımızı kolaylaştırırken, öte yandan gerçek ve kurgu arasındaki uçurumun oluşmasına neden olmaktadır. Bilginin üretildiği, yansıtıldığı ve çarpıtıldığı bir araç olan medya, bilgiyi depolayan ve aktaran araçlar olarak karşımıza çıkmaktadır. Birey gerçeğe ulaşmak adına buradan edindikleriyle kendi yaşam deneyimlerini karşılaştırmakta, elde edilen sonuç onların tutum ve davranışlarında değişikliğe yol açmaktadır.

Televizyonda yer alan haberlerin gerçekliği, bir takım görsel imgelere dayanmasından kaynaklanmaktadır. Poyraz'ın (2002: 70) da ifade ettiği gibi, "Görsel metin içinde göndergeye ilişkin hiçbir şey yoktur. Oysa izleyici göstereni gönderge ile özdeşleştirir ve gerçeğe tanık olduğuna inanır. Televizyon haberlerinde gerçekliğin farklı bir görünüme bürünmesini sağlayan en önemli unsur dramatik öğelerdir. Haberlerde, özellikle de haber programlarında, geniş bir izleyici kitlesine seslenebilmek için, ağırlıklı olarak ele alınan olayların duygusal boyutları öne çıkarılmaktadır. Öyle ki, tamamen gerçek olaylara ve karakterlere dayalı olan haber ve haber programlarında bile, hakiki gerçeklik kurmaca gibi, geleneksel anlatı saymacalarıyla yeniden kurulmuştur. Yani gerçek; insanları, soruları, olayları (iyi-kötü, kahraman-kötü adam, bireykurum, biz-düşmanlarımız, doğa-kültür gibi) iki karşıt gücün çatışmasıyla nitelenen anlatılara dönüştürmüştür".

İletişim sürecinde iknanın oluşması noktasında, kaynağın güvenilir ve saygınlığı önem taşımaktadır. Kaynağın güvenilirliğinin düşük olması noktasında, algının beklenildiği yönde oluşması da mümkün olmamaktadır. Bunun dışında mesajın içeriği, hangi kanallar ile hedef kitleye ulaşacağı, hedef kitlenin analizi gibi konular da iletişimin başarısında rol oynamaktadır. İletilen mesajın inandırıcı olması durumunda, amaçlanan ikna ve etkileme olayı gerçekleşecektir. Kepplinger'e (2003: 11) göre medya içerikleri alımlayıcılar tarafından benzer şekilde algılanmakta ve bunun sonucu olarak benzer etkilere yol açmaktadır. Uyarıcıların sıklığının artması ile oluşan tepkiler arasında doğrusal bir ilişki bulunmaktadır.

Haberin gerçekliği noktasında 3 farklı gerçeklikten söz edilmektedir. Medyada haber olarak yayınlanan olayın hakikat durumunu ifade eden özgün gerçeklikte, yazarın yorumu ve kurgusu yer almamakta, olay aktaran tarafından bilinmektedir. Haberciden beklenen yorumsuz olarak elde edilen gerçekliğin medya yoluyla aktarılmasıdır. Bu noktada görüntünün çekilme biçiminden, bireyin olayın gerçekleştiği yerdeki bulunuş durumuna kadar objektifliği etkilemekte, olaylar haberi yapanın penceresinden kamuoyuna ulaşmaktadır. Gerçek kurgulanmış ve şekillenmiştir. Sunumsal gerçeklik olarak adlandırılan bu durumda okuduğumuz, izlediğimiz haberler gerçek olmamakta, gerçeğin kurgulanmış sunumu olarak karşımıza çıkmaktadır Medya mevcut gerçeği kendi değerlendirme süzgecinden geçirerek aktarmakta, bu şekilde okur ya da izleyiciyi etkileme yolunu seçmektedir. Algısal gerçeklik olarak adlandırılan durumda ise haber ileticisi tarafından aktarılan öznel gerçeklik, okur tarafından yeniden şekillendirilmektedir. Bu şekilde okur ya da izleyici kendisi gerçekliğini oluşturacak, kurgusal gerçekliğe katılmayacaktır. 
Medyanın gerçekliği manipüle ederek, kendi gerçekliğini oluşturması konusu sıkça tartışılmakta, bu etkilerin boyutu ve sınırları noktasında farklı görüşler ileri sürülmektedir. Ünlü iletişim bilimci McLuhan (2019: 67) görsel kültürün batı medeniyetinin paradigmasını oluşturan en önemli öğelerden biri olduğunu ifade etmektedir. Ona göre; "Görsel uzam tek tip, süreğen ve bağıntılıdır. Bizim batı kültürümüzde rasyonel insan, görsel insandır. Batı insanı görselliği olmayan şeyleri idrak edemez. Bunlarla ilgili bilinç deneyimlemesi yapamaz. Benliğimizi tümüyle medya teslim aldı. Kitle iletişim araçları kişisel hayatımızı, siyasal ekonomik vs. hayatımızı öylesine yaygın biçimde etkilemektedir ki, ilişmedikleri, dokunmadıkları, değiştirmedikleri hiçbir yanımız kalmadı". Medyanın görsel öğelere ağırlık vererek, kurgusal olması toplumların manipüle edilmesini kolaylaştırmaktadır.

Medyanın toplumsal gerçeklikle olan bağlantısı; üç farklı yaklaşım çerçevesinde ele alınmaktadır. Liberal çoğulcu medya kuramı çerçevesinde medyanın toplumsal gerçekliği olduğu gibi yansıttı̆̆ ileri sürülmekte, toplumsal alanda var olan çeşitliliğin ve çoğulculuğun medya tarafından temsil edildiği vurgulanmaktadır. Medya kendisini toplumsal sorumluluk ilkesi doğrultusunda yasama, yürütme ve yargıdan sonra dördüncü güç olarak konumlandırmaktadır. Marksist yaklaşım ise, medyanın toplumsal gerçekliği bozan ve çarpıtan işleyiş̧ine odaklanmaktadır. Buna göre, tahakküm ilişkilerinin sürdürülebilmesi için toplumsal gerçekliğin çarpıtılması gerekmektedir. Bu açıdan kitle iletişim araçlarına düşen, insanların mevcut üretim ilişkilerini sürdürecek toplumsal ilişkilere rıza göstermesinin sağlanmasıdır. Bu bağlamda egemenlik ilişkilerinin üretimi, ideolojik ve kültürel anlam sistemlerinin üretilmesiyle mümkün olmaktadır. Medya bunu gerçekleştirdiği ölçüde, ideolojik işlevlerini yerine getirmektedir. Eleştirel yaklaşımlar medyayı, gerçekliğin edilgin bir aktarıcısı olarak değil, etkin ve kurucu bir alanı olarak görmektedir. İnsan kendi deneyimini ona ilişkin belirli bir anlam inşa ederek bilmektedir. $\mathrm{Bu}$ noktada medya toplumsal gerçekliğe ilişkin anlamların en merkezi dolayımlayıcısı olarak rol oynamaktadır. Fenomenolojik yaklaşım ise; toplumsal bilginin hem medya hem de izleyici/okur kitleleri tarafından birlikte gerçekleştirilen bir süreç olduğuna odaklanmaktadır. Bireyler kendi kimliklerini ve öznel dünyalarını, medyanın inşa ettiği sembolik gerçeklik çerçevesinde inşa etmektedir.

Günümüzde toplumları etkileme ve yönlendirme gücüne sahip olan medya, gerçekliğin oluşmasında da önemli rol oynamakta, ancak bu gerçekliğin algılanması noktasında algılayanların özellikleri etkili olmaktadır. Gerçeğin doğru anlaşılması veya algılanmasında medya tüketicilerinin kişisel özellikleri, değerleri, kitle iletişim araçlarını tüketim alışkanlıkları gibi faktörler belirleyici olmaktadır.

Potter (2005: 61), medya iletileri tarafından kuşatıldığımız içinde bulunduğumuz 21.yüzyılda bireylerin gerçek dünya ve medya dünyası olmak üzere iki farklı dünyada yaşadığını belirtmektedir. Gerçek dünya, kendi yaşamımızda doğrudan tecrübe ettiğimiz kişisel deneyimlerimize dayanırken, medya dünyası ise kitle iletişim araçları tarafından aktarılan yaşantı ve deneyimleri ihtiva etmektedir.

Sanders (1999:135) bir çocuğun altı yaşından on sekiz yaşına gelene kadar 16 bin saat televizyon seyrettiğini, radyo ve CD dinleyerek 4 bin saat geçirdiğini, bilgisayar karşısında 5 bin saat harcadığını ve 2 bin saatini de sinemada geçirdiğini belirtmektedir. 6-18 yaş arasındaki dönemin yüzde 25 'ten fazlasını medya araçları karşısında geçiren çocuklar, medya dünyası ile gerçek dünya arasında ayrım yapmakta sıkıntılar yaşamaktadır. Toylar ve Howell'in ifade ettiği gibi (1973: 317) çocuklar özellikle televizyonu sihirli bir pencere olarak algılamakta, gerçek ve kurgu arasında ayrım yapmakta zorlanmaktadırlar. 12 yaşına dek birçok çocuk gerçek ve fantastik dünyanın ayrımına varamamaktadır (Hawkins, 1977: 195; Van der Voort, 1986: 176; Wright ve Diğerleri, 1994: 232; Potter, 2005: 62; Livingstone, 2006: 4). Gerçekliğin nasıl algılandığı ile ilgili olarak sorunlar sadece çocukların algılamalarıyla sınırlı değildir. Potter (2005: 63), medyanın 
yetişkin ya da çocuk ayrımı yapmaksızın herkesin gerçeklik algısına etki ettiğini belirtmektedir. Medya ve gerçeklik algısı ile ilgili problem büyük ya da küçük herkeste görülebilmektedir. Uysal (2006: 123), ülkemizde gerçek dünya ile medyanın kurmaca dünyası arasındaki ayrımı kaybeden birçok yetişkin bireyin, dizi kahramanlarının cenaze namazını kıldığını, gerçek dünyada işlenen bir cinayetin failiyle ilgilenmek yerine dizideki kahramanın katilini öğrenebilmek için kanalın telefonlarını kilitlediklerini belirtmektedir.

Postman'ın da (1995:102) ifade ettiği gibi, çocuklar için medya dünyası ile gerçek dünyanın ayrımına varamama, onların yeterli gelişimsel özelliklere sahip olmamasından kaynaklanan bir durum olsa da yetişkinler için daha kötü olan, medya dünyasının gerçeklerini sorgulamaksızın kabullenmekten kaynaklanmaktadır. Medya araçlarının hepsinde "gerçeklik" sorunu karşımıza çıkmasına karşın, sihirli pencere olarak adlandırılan ve en etkili medya aracı olarak kabul gören televizyon sektörü için bu sorun daha da belirgindir.

Yetişkinler gerçeklikle ilgili algılarını "sosyal yarar sağlama" ve "özdeşlik kurma" ilkeleri çerçevesinde şekillendirmektedir (Dorr,1981:335; Hawkins,1977: 223; Potter,1986: 165). Sosyal yarar beklentisi içerisinde olan bireyler, medya aracılığıyla kendilerine ulaşan iletileri ancak gerçek hayatta kullanabileceklerine inandıkları ölçüde doğru olarak algılamaktadır. Özdeşlik kurma ise, medya iletileri ile kişilerin beklentilerinin, arzularının ve özlemlerinin örtüşmesini ifade etmektedir. Potter'in (2005: 67) ifade ettiği gibi, medya üreticileri, bireylerin sosyal yarar ve özdeşliğe karşı güdülendiklerinin bilinciyle iletilerini kurgulamaktadır. Medya sektörü, hedef kitlesini yakından tanımakta ve iletilerini onların beklentileri doğrultusunda hazırlama yoluna gitmektedir.

Bireyler medya aracıllğıyla bilgilenmekte, çevrelerinde olup bitenlerden kısa süre içerisinde haberdar olabilmektedir. Bu çabanın daha az zaman ve maliyet gerektirmesinden ötürü, bireyler kitle iletişim araçlarına bağımlı bir şekilde yaşamlarını sürdürmeye devam etmektedir (Potter, 2005:65). Burada önemli olan medya görüntülerinin ve iletilerinin gerçeğin kendisi değil, gerçeğin bir yansıması olduğunun bilinciyle hareket etme becerisine sahip olabilmektir (Natharius,2004: 240). Arık ve Solmaz'ın (2007:255) da belirttiği gibi, "Kitle iletişim araçları, toplumsal norm ve değerlerin oluşmasında bireyin zihnindeki imajları kullanır ve kusursuz bir dünya yaratır. Gerçek olmayan olaylar kurgulanarak yeniden desenlenir, böylece gerçekleri saklayarak oluşturulan imaj ve kurgulanan yapı kendini ön plana çıkarır. Haberleşme yoluyla oluşturulan kurgusal ve yapay dünya gerçek yaşamın yerini alır". Bunun sonucu olarak da bireyler sıklıkla medya kültürü tarafından yönlendirildiklerinin farkına varamamaktadır (Kellner ve Share, 2007: 4)

Medya araçlarından gelen iletiler bireylerin bilgi yapılarını şekillendirmekte, kişinin algı yapısını oluşturarak yaşam deneyimlerini sınırlandırmaktadır. Tyner'in (1993: 92) belirttiği gibi, medya iletilerine maruz kalan birey, kendi yaşamıla medya iletilerini karşılaştırmakta, bunun sonucunda da çoğunlukla kendi deneyimlerini terk ederek, medya deneyimlerini benimseme yoluna gitmektedir.

Günümüzün ticari ortamında medya kuruluşları reklam gelirlerini arttırabilmek amaciyla gerçekleri çarpıtarak, abartma yoluna gidebilmektedir (Buckingham, 1993: 84; Potter, 2005: 73). Medyanın sunduğu şeyler gerçekliğin birebir yansıması olmayıp, sadece bir temsilidir. Medya bu temsilciler vasıtasıyla bilgi yapılarımızı yeniden şekillendirmektedir. McLaren (2007: 125), bilgi inşasının iktidar sahiplerinin en güçlü silahı olduğunu ve günümüzde artık bilgi üretiminin politik etkilerinden birisinin de belli grupların seslerini meşrulaştırmak ve onlara daha az ayrıcalıklı olanların seslerinden daha fazla inanılırlık katmak olduğunu belirtmektedir.

"Teaching the Media" adlı eserinde Len Masterman (1985: 43) medya eğitimini; bilgiyi kendi çıkarları doğrultusunda üretenler ile bu bilgiyi haber ve eğlence formatında masum bir şekilde 
tüketenler arasında ortaya çıkan bir etkileşim olarak tanımlamaktadır: "Medya eğitimi, bilme ve iktidar ilişkilerindeki büyük eşitsizliklere meydan okuma sürecindeki öğretmen ve öğrencilerin sahip olduğu sınırlı sayıda araçlardan biri olarak görülmektedir. Medya okuryazarlığı eğitiminin temelinde medyaya karşı aşırı korumacı bir yaklaşımdan ziyade, bireyleri medya konusunda bilgilendirerek onların medya iletilerine karşı eleştirel yaklaşımlarını sağlamak bulunmaktadır".

Bireyleri medyanın işleyişi konusunda bilgilendirerek, medya etkileri konusunda bilinçlendirme amacında olan medya okuryazarlığı eğitimi; modern dünyanın eğitim sistemi içerisinde önemli bir yere sahiptir. Medya okuryazarlığındaki temel amaçlar; medyanın ilettiği mesajların doğru okunması, kişiye medyanın sunduğu dünyanın gerçek olmayabileceğini anlatması, medyanın yönetme fonksiyonun da olduğunun farkına varması gibi hedefleri içermektedir. Medya okuryazarlığı eğitimi medyayı doğru okuyan, çözümleyen, kitle iletişim araçlarından gelen iletilere eleştirel bakan bireyler yetiştirmeyi amaçlar. Medya okuryazarlığı olarak kullanılmaktadır (Buckingham,2003:4). Dolayısıyla medya okuryazarı, medyada yeniden kurgulanan iletileri ayırt edebilmek ve algilayabilmek, onunla ilgili yorumlarda bulunabilmek için ayrı bir beceri, altyapı bilgisi ve eğitsel organizasyon gerektiren bir eğitim sürecinin sonucu olarak medya yetkini sıfatını kazanan kişiyi betimleyen bir terimdir (Taşkıran, 2007:7).

Şahin ve Tüzel'in (2011:130) de ifade ettiği gibi; "Meselenin çözümü medya kuruluşları aracılığıyla arandığında, medya kuruluşlarının haber verme ve bilgilendirme işlevlerini yerine getirirken gerçekleri kurgu karmaşasına mahkûm etmeden, olabildiğince yüksek oranda yansıtmaları gerekir. Medya kuruluşlarının sahipleri ya da çalışanlarının, kişisel inanç, değer ve çıarlarının gerçeğin önüne geçmesinden ve gerçeğin üzerinin örtülmesinden kaçınmaları gerekir. Medya kuruluşlarının bu kaygıları gütmemeleri durumunda ise resmi organlar aracılığıyla caydırıcı yaptırımlara gidilmelidir. Ülkemizde ve dünyada çeşitli kuruluşlar aracılığıyla medya denetimine yönelik önlemler alınmaktadır. Ancak medya şirketlerinin günümüzde ulaştığı ekonomik ve siyasi boyutlar göz önüne alındığında, bu önlemlerin etkililiği ve bağımsızlığı tartışma konusu olabilmektedir. Meselenin çözümüne birey odaklı bir bakış açısıyla yaklaşıldığında ise medya okuryazarlığı eğitiminin güçlenen bir değer olarak karşımıza çıktığı görülmektedir Medya iletilerini ne kadar acımasız ve saldırganca kurgularsa kurgulasın, medya konusunda bilişsel farkındalık düzeyine ulaşmış bireyler bu iletilerin art alanlarını çözümleyip işleyecek yetkinliğe sahip olacaklardır".

Günümüzde gündelik yaşamın ayrılmaz bir parçası haline gelen sosyal medya; Facebook, Twitter, Instagram gibi platformlarıyla yaşamın pek çok alanında kişilerin algılarını, davranışlarını, seçimlerini etkileyen bir boyuta ulaşmıştır (High ve Solomon, 2010:130). Başıbüyük'ün de (2014: 59) belirttiği gibi; “Geleneksel medya karşısında sosyal medya, kullanıcı temelli bilgi üretimine imkân sağlaması, üretilen mesaj ve bilginin çok hızlı bir şekilde, uzun mesafelere ve büyük kalabalıklara en ekonomik şekilde ulaştırılması, geniş ve herkese açık kullanımı nedeniyle üretilen bilginin kullanıcılar arasında denetiminin hızla sağlanması (kısa sürede yalanlanması ya da doğrulanması) özellikleri ile algı yönetimi, kamuoyu oluşumu ve kamuoyunun yönlendirilmesi alanlarında güçlü etkilere sahiptir".

Chomsky'e (2002: 10) göre; medyadaki gerçeklik sorunu, kaotik dönemlerde, medyanın özgürlük arayışını zayıflatıp-zayıflatmadığı ile ilişki içerisindedir. Egemen medya, bağımlı olduğu kesimin çıarları ekseninde bilgiyi farklı işlemlerden geçiren; gizleme gereği duyan, konjonktüre göre; var olmayan bilgiler icat etme eğilimi göstermek suretiyle, gerçeği manipüle eden bir araç görevi üstlenmektedir. Bu açıdan bakıldığında medyanın toplumsal bir amaca hizmet ettiği argümanı, günümüz toplumlarında alternatif bir söylem olarak yerini almaktadır.

Kitlelerin nelerden haberdar olacağından, nelerin tartışılacağına kadar tüm süreçleri sistemli bir şekilde inşa eden medya, aynı zamanda egemen düşüncenin zihinlerde inşa edilmesini 
sağlamaktadır. Barret'in (1996: 65) ifadesiyle bu durum rızanın medya tarafından üretilmesi olarak karşımıza çıkmaktadır. Gerçeklik bize iktidar ve onun ideolojik aygıtlarından biri olan medya tarafından fark ettirmeden verilmektedir. "Neyin haber olarak seçileceğine ve nasıl yayımlanacağına karar veren medya, diğer kar amaçlı kurumlardan farklı değildir. Onun da satacağı bir ürün vardır. Hiçbir gücün sonsuza kadar zor kullanarak devam edemeyeceğini ve yönetici sınıfın iktidarını ve gücünü sürdürmek için kamu rızasının ancak ikna yoluyla alınacağını savunan Hackett ve diğer araştırmacılar, medyanın bu rızayı üreten en önemli kurum olduğu üzerinde uzlaşmaktadırlar (Mora, 2008: 55).

Toplumların anlam dünyasını sistematik bir şekilde belirli bir ideoloji çerçevesinde düzenleyen medya; medyada gerçeğin temsilinde belirleyici konumdadır. Burada medyanın sahiplik ve mülkiyet yapısı, önemli rol oynamaktadır. Günümüzde medya endüstrisi, tüm dünyada finansal örgütlenmeler başta olmak üzere çok sayıda güç merkezi ile yakın ilişki içerisindedir (Bagdikian,2004: 49). Bu durum, toplumu bilgilendirme misyonu taşıyan medya kuruluşlarının, sermaye sahiplerinin kontrolü altına girmesine yol açmaktadır. Egemen gücün ideolojisinin yeniden üretilerek, iktidar ile halk arasındaki ilişkilerin düzenlenmesinde önemli rol oynayan medya, günümüzde ideolojik bir aygit olarak egemen güçlerin kontrolündeki ticari bir faaliyet alanı görünümüne kavuşmuştur.

Daha önceden belirli bir kesimin tekelinde bulunan bilgi, günümüzün teknolojik gelişmeleri sayesinde en kısa sürede tüm dünyaya yayılmakta, coğrafya, cinsiyet, dil ve din ayrımı yapmaksızın, geniş kitleleri yoğun bir şekilde etkilemektedir (Dinçer ve Yılmazkol, 2009: 189). Bilginin bu denli hızlı ve kontrolsüz yayılımı, bilgi karmaşasına yol açmakta, bu da bireylerin gerçeğe ilişkin algılarında önemli sorunlar yaşanmasına yol açmaktadır (Yazgan ve Kıncal, 2009: 517). Bell'in de vurguladığı gibi sanayi sonrası topluma geçişle birlikte iktidarla bilgi arasındaki ilişki giderek güçlenmiş, (Baran, 1992: 54) iktidarda yer alabilmenin yegâne koşulu, bilgiye sahip olmakla eşdeğer görülmeye başlanmıştır. Günümüz toplumlarında bilginin üretimi, denetlenmesi ve dağıtımı olmaksızın egemenlerin varlığını sürdürmeleri mümkün olmamaktadır (Foucault, 2003: 131). Bilgi, içinde bulunduğumuz 21.yüzyılda, tüm insani faaliyetlerin düzenlenmesinde etkin rol oynamaktadır.

Kitle iletişim araçları aracılığıyla kendisine ulaşan iletileri algılayan birey medyanın yönlendirdiği gerçeklik illüzyonu içerisinde yaşamaktadır. Marcuse'un dediği gibi artık gerçeğe ilişkin düşünmemiz medyanın tanımladığı kavramlara bağlıdır (Koç, 2018: 12). Medya iletilerine maruz kalan bireyler Baudrilliard'ın (2005: 56) ifade ettiği gibi, kurgulanmış bir gerçeğin içinde yaşamaya başlayan sessiz yığınlar haline gelmekte, kurgulanan gerçek artık hakikatin yerini almaya başlamaktadır. Onun yönteminin hareket noktası simülasyondur. "Bir gerçeklikten yoksun gerçeğin modeller aracilığıyla türetilmesine hiper gerçek yani simülasyon denilmektedir" (Baudrillard, 2011:14). Baurdrillirad, gerçeğin yerini alabilen "Simülakra"lardan bahsetmekte, bir simülasyon çağından söz etmektedir. Ona göre artık rasyonel bir gerçeğe gerek yoktur, çünkü işlemsel bir gerçek vardır ve kendini sentetik bir şekilde üreten bir gerçek olarak vardır.

Baudrillard'a göre "Hiper gerçeklik" gerçeklikten daha fazla bir şeydir. Medyanın, eğlencenin kitle iletişim araçlarının ve enformasyon teknolojilerinin insan hayatında bu anlamda etkili olduğunu vurgulayan Baudrilliard'a (2011:30) göre, "Hiper gerçek, düşünceyi ve gerçekliği kontrol eder. Hiper gerçeklikten sonra artık gerçekliğe ihtiyaç yoktur". Televizyonun aktif rolü üzerinde duran Baudrilliard, panoptikon kavramı ile kuşatılmışlığın derecesini ifade eder. Ona göre post-modern insanın hakikati televizyondur. Hiper gerçekliğin hakikat ile ilişkisinde Baudrillard "Hologram" örneğini verir. "Hologram asılıp geçilmiş, bir hakikat simülasyonu bir başka deyişle hakikat ötesi bir hakikat simülasyonudur" (Baudrillard, 2011: 154). 
Sosyal medya platformlarında nesnel gerçeklikten koparılan bilgi, yeniden kurgulanarak hedef kitlelere iletilmektedir. Sanal alemde bilgi bombardımanı altında binlerce bilgi arasından en doğruyu seçmek giderek zorlaşmakta, tüketim metası haline getirilen bilgi; medyanın ideolojisi ve bilgiyi üreten kurum ve kişilerin ideolojileri ile özdeş hale gelmektedir.

Günümüzün karmaşıklaşan toplumlarında gerçeklik insanlara medya araçları tarafından sunulmakta, çevrelerinde olup bitenler hakkında bilgi sahibi olması sağlanmaktadır, İnsanları bir deneyim alanı ile buluşturan medya, onlara başka deneyim alanları sunmaktadır. Bireylerin kendi deneyimleri ile algıladığı gerçeklik ile medya gerçekliği arasındaki fark, toplumsal gerçeklik alanını yapılanmasını sağlamaktadır. Medya farklı zaman ve mekan bağlamlarındaki bireylere sembolik bir içeriği aktarmakta, bu sayede gerçekliğin inşası sağlanmaktadır. Medya bireylerin gerçeklikle bağlantısını güçlü biçimde yapılandırmakta, medya tüketicileri bu sayede hiç yaşamadığı/yaşayamayacağı deneyim alanlarına tanıklık etmekte, bunlara ilişkin anlamlar üreterek toplumsal gerçekliğin inşasına katkı sunmaktadır.

Lippmann 'Kamuoyu' adlı eserinde haber ve gerçeğin aynı şey olmadığını, birbirlerinden ayrılması gerektiğini ifade etmektedir. Ona göre haber bir olayla ilgili iken, gerçek; gizli saklı kalmış olayları ortaya çıkararak, insanların onlar hakkında bir değerlendirme yapmasını sağlamaktadır (Poyraz, 2002: 61). Gerçeklik sayesinde egemen ideolojinin hegemonyasını sürdürmesi sağlanırken, medya aracılığıyla insanlara gerçek değil, onun yerine kurgulanan gerçek gösterilmektedir. Baudrilliard'ın (2005: 14) ifadesiyle, ideolojik bir aygit olarak medya, egemenlerin ideolojisini yayma ve yeniden üretme konusunda büyük önem taşımaktadır: "Haber ve bilgi sunulurken beraberinde egemen kültür ve ideoloji de sunulmakta, bireyler egemen kültür ve ideoloji çerçevesinde önemli kabul edilen bilgileri ve haberleri öğrenmektedir. Medya, egemenlerin hegemonyalarını sağlamlaştırması ve toplumsal rızanın sağlanması açısından yeri doldurulmaz bir araçtır. Gerçeklik bize iktidar ve onun ideolojik aygıtlarından biri olan medya tarafından fark ettirilmeden verilmektedir. Gerçekliğin algılanması bile medya aracıllı̆ı̆yla topluma öğretilmekte, insanlara gerçek değil onun yerine kurgulanan gerçek gösterilmektedir".

\section{SONUÇ}

Kitle iletişim teknolojisindeki gelişmeler bir yandan hayatımızı kolaylaştırırken, öte yandan gerçek ve yanılsama arasındaki ayrımın giderek kaybolmasına yol açmaktadır. Bireyler gerçeğe ulaşmak için burada gördükleriyle, kendi yaşamlarından elde ettikleri deneyimleri karşılaştırmakta, bilgi şemaları bu çerçevede şekillenmektedir. Bireylerin kendi deneyimleri ile algıladığı gerçeklik ile medya gerçekliği arasındaki fark, toplumsal gerçeklik alanının yapılanmasını sağlamaktadır. Medya bireylerin gerçeklikle bağlantısını güçlü biçimde yapılandırırken, medya tüketicileri bu sayede hiç yaşamadığı/yaşayamayacağı deneyim alanlarına tanıklık etmekte, bunlara ilişkin anlamlar üretmektedir. Günümüzde zihinlerin inşasının kaynağı konumunda olan medya aracılığıyla, ekonomiden siyasete, kültürden sosyal ilişkilere kadar yeni algı kalıplarının oluşması sağlanmakta, bu sayede düşünme ve eylem biçimlerimiz, kültürel ve sosyal hayatımız bu çerçevede oluşmaktadır.

Günümüzün modern bireyleri çevrelerinde olup bitenlerden medya aracllı̆̆ıyla enformasyon edinmekte, özellikle sosyal medyanın maliyet ve zaman açısından elverişli olması nedeniyle bu araçlara bağımlı bir şekilde yaşamlarını sürdürmektedir. Bu süreçte sosyal medya alternatif bir mecra olarak karşımıza çıkarken, algıların yönetimi dijital dünya üzerinden kurgulanmaya başlanmıştır.

Algı ve gerçeklik arasındaki uçurum modern dünya ile daha da genişlemiş, iletişim araçları bireylerin zihin şemalarının oluşmasında ve algılarının yönetiminde önemli işlevler üstlenmiştir. 
Bu noktada dikkat edilmesi gereken, medya görüntülerinin ve iletilerinin gerçeğin kendisi değil, gerçeğin bir yansıması olduğu bilinciyle hareket etme becerisine sahip olabilmektir.

Medya aracılığıyla sunulan açık veya örtük iletilerin kabulü veya içselleştirilmesi sürecinden sonra, izleyici/okuyucu belli başlı davranış örüntüleri gerçekleştirmektedir. Bu etki; şiddet sahnelerini taklit etmekten, yeni tüketim alışkanlıkları geliştirmeye; modayı takip etmekten, ekranda sunulan rol modellerini örnek almak gibi farklı şekillerde ortaya çıkabilmektedir. Gerçek dünya ile medyanın kurmaca dünyası arasındaki ayrımın kaybedilmesi durumunda, gerçek yaşamda dizi kahramanlarının cenaze namazlarının kılındığına tanık olunmaktadır. Gerçek ile kurgu arasındaki ayrımın belirlenmesi noktasında medya okuryazarlığı yetkinliği önemli bir beceri olarak karşımıza çıkmaktadır.

Bireyleri medyanın işleyişi ve etkileri konusunda bilinçlendirme amacı güden medya okuryazarlığı, modern dünyanın eğitim sistemi içerisinde önemli bir yere sahiptir. Medya tüketicileri, medya ürünlerine karşı eleştirel okuma yaparak, medyanın hayatın gerçekliğini ne kadar yansıttığı noktasında eleştirel bakış açısına sahip olmalı, medya dünyası ile gerçek dünyayı karşılaştırarak bilgi yapılarını oluşturmalıdır. Bu noktada bireylerin kendilerine ulaşan mesajların doğruluğunu başka medya araçlarında teyit etmeleri, bilginin güvenilirliği açısından önem taşımaktadır.

Bilginin sürekli yenilendiği çağımızda bireylerin medya araçları karşısında eleştirel düşünme becerilerini geliştirmeleri bir gereklilik olarak karşımıza çıkmaktadır. Medya tüketicilerinin medya iletileri karşısında bilişsel farkındalık düzeyine ulaşmaları, gerçek ve kurgu arasındaki ayrımın yapılması noktasında önem taşımaktadır. Medya kuruluşları haber verme ve bilgilendirme işlevlerini yerine getirirken, gerçekleri yansıtmaya özen göstermeli, kişisel inanç, değer ve çıkarlarının gerçeğin önüne geçmesine izin vermemelidir. Haberin veya bilginin kaynağını sorgulayarak, medyada karşılaşılan enformasyona eleştirel bir bakış açısıyla yaklaşmak, bilgilerin gerçeği yansıtıp yansıtmadığını araştırmak bu noktada önem taşımaktadır. Bu enformasyonu kim, niçin üretmiş, yayınlanma amacı ne, medyanın ekonomi-politik yapısı bu haberin yayınlanmasında etkili olmuş mudur? vb. gibi soruların sorulması, medya metinlerinde sağlıklı enformasyona ulaşma noktasında katkı koyacaktır.

\section{KAYNAKÇA}

Akarsu, B. (1984). Felsefe Terimleri Sözlü̆̆̈̈, Gerçek Maddesi. Ankara: Savaş Yayınları.

Arık, B. ve Solmaz, B. (2007). Kitle İletişim Araçlarında Gerçeğe Bürünen Kurgu: Orhan Pamuk Edebiyat Ödülü Örneği. (Editör): Bilgili, C. ve Akbulut, N.T. Medya Eleştirileri 2007: Gerçeğin Dışındakiler içinde (s. 233-257). İstanbul: Beta Yayın Dağıtım.

Bagdikian, B. (2004). New Media Monopoly. Boston: Beacon Press.

Bakan, İ. ve Kefe, İ. (2012). Kurumsal Açıdan Algı ve Algı Yönetimi. Kahramanmaraş Sütçü İmam Üniversitesi, İ̈BF Dergisi, 2(1): 19-34.

Baudrillard, J. (2005). Simülaklar ve Simülasyon (Çeviren: Adanır, O.) İstanbul: Doğu- Batı Yayınları.

Baudrilliard, J. (2011). Simülakrlar ve Simülasyon, İstanbul: Doğu Batı Yayınları.

Baran, A. (1992). Sanayi Sonrası Enformasyon Toplumu Üzerine Tartışmalar. Hacettepe Üniversitesi Edebiyat Fakültesi Dergisi, 9(1): 53-69.

Barrett, M. (1996). Marx'tan Foucault'a İdeoloji. İstanbul: Sarmal Yayınevi. 
Başıbüyük O. (2014). Algı Yönetimi ve Bilgi Savaşlarında Sosyal Medyanın Rolü. (Editör: Karabulut, B.). Alg̨ Yönetimi içinde (s. 39-65). İstanbul: Alfa Yayınları.

Buckingham, D. (1993). Watching Media Learning: Making Sense of Media Education. London: Falmer.

Callamari P. and D. Reveron (2003). Chine's Use of Perception Management. International Journal of Intelligence and Counter Intelligence, (16): 1-15.

Chomsky, N. (2002). Medya Gerçeği. İstanbul: Everest Yayınları

Dincer, M. ve Yılmazkol, Ö. (2009). Televizyon Çocuklara Gerçek Hayatı Şiddetle Öğreten Çağdaş Masal Anlatıcısı. (Editör: Akçalı, S.), Çocuk ve Medya içinde (189-211) Ankara: Nobel Yayın Dağıtım.

Dorr, A. (1981). Television and affective development and functioning; maybe this decade. Journal of Broadcasting, (25): 335-345.

Entman, R.M. (1993). Framing: Toward clarification of a fractured paradigm. Journal of Communication, 43(4): 51-58.

Foucault, M. (2003). İktidarın Gözü. İstanbul: Ayrıntı Yayınları.

Garfield, A. (2002). The Offence of Strategic Influence: Making the Case for Perception Management Operations. Journal of Information Warfare, 1(3): 30-39.

Gezgin, S. (2002). Medyada ve Eğitimde Birikimlerim. İstanbul: İstanbul Üniversitesi İletişim Fakültesi Yayınları.

Gültekin, M. (2016). Algı Yönetimi ve Manipülasyon. İstanbul: Pınar Yayınları.

Hawkins, R. P. (1977). The dimensional structure of children's perceptions of television reality. Communication Research, (7): 193-226.

High, A.C. and D.H. Solomon (2011). Locating Computer-Mediated Social Support Within Online Communication Environments. Computer-mediated communication in personal relationships. 119-136, New York: Hampton Press.

İnceoğlu, M. (2011). Tutum Algı İletişim. (6. bs.), Ankara: Siyasal Kitabevi.

Kars, N. (2010). Radyo-Televizyon Haberciliği. İstanbul: Derin Yayınları.

Kellner, D. and Share, J. (2007). Critical Media Literacy, Democracy and the Reconstruction of Education. (Ed. Macedo D. and Steinberg S.R.). Media Literacy: A Reader içinde (s. 3-23). New York: Peter Lang

Kepplinger, H.M. (2003). Etki Kavramının Sınırları. (Der. Çebi, M.), Medya Etki Araştırmaları, içinde (s.11-33), Ankara: Alternatif Yayınları.

Kissenger, H. (2016). Diplomasi. (çev. Kurt, İ. ), İstanbul: Türkiye İş Bankası Kültür Yayınları.

Koç, A. K. (2018). Gerçeklik, Dil, Medya ve Manipülasyon. Uluslararası Sosyal Araştırmalar Dergisi, 11 (56): 23-35.

Le Bon, G. (2014). Kitleler Psikolojisi. (çeviren: Can, H.). Ankara: Tutku Yayınevi.

Lilleker, D. G. (2013). Siyasal İletişim: Temel Kavramlar. (Çeviren: Ekşi, B.). İstanbul: Kaknüs Yayınları.

Lippmann, W. (1998). Public Opinion: With a New Introduction by Micheal Curtis,New Branswick and London: Transaction Publishers, (Orginal work published 1922) 
Livingstone, S. (2006). Media Literacy and the Challenge of New Information and Communication Technologies. The Communication Review, 7 (1): 3-14.

Masterdam, L. (1985). Teaching the Media. London: Comedia Publication Group

Mclaren, P. (2007). Kapitalistler, İşgalciler: Imparatorluğa Karşı Eleştirel Bir Pedegoji. İstanbul: Kalkedon Yayınları.

McLuhan, M. (2005). Yaradanımız Medya. (çev. Oskay Ü.), İstanbul: Merkez Kitaplar.

McMahon, G. (2009). Critical Thinking and ICT Integration in a Western Australian Secondary School. Educational Technology and Society, 12 (4), 269-281

Mora, N. (2008). Medya Çalışmaları, Medya Pedagojisi ve Küresel İletişim. İstanbul: Alt Kitap.

Morresi, E. (2003). Haber Etiği, (çev: Genç, F.), Ankara: Dost Kitabevi Yayınları.

Morris, C. G. (2002). Psikolojiyi Anlamak. (Çev. Ayvaşık, B.ve Sayıl, M.) Ankara: Türk Psikologlar Derneği Yayınları.

Mutlu, E. (2000). İletişim Sözlüğüu. Ankara: Sofos Yayınları.

Natharius, D. (2004). The more we know, the more we see: The role of visuality in media literacy. American Behavioral Scientist, (48): 238-247.

Öksüz, H. (2013). Algı Yönetimi ve Sosyal Medya İdarecinin Sesi, 2013, /156.Sayı/3 erişim: 15-04-2018. www.tid.web.tr/ortak_icerik/tid.web

Özer, M. A. (2012). Bir Modern Yönetim Tekniği Olarak Algılama Yönetimi ve İç Güvenlik Hizmetleri. Karadeniz Araştırmaları, (33): 147-180.

$\begin{array}{lllll}\text { Perception, Process and terminology. Erişim Tarihi: 07.07.2018. } & \text { and }\end{array}$ http://enclopedia.thefreedictionary.com/Perception management.

Postman, N. (1995). Çocukluğun Yokoluşu (Çeviren: İnal, K.), Ankara, İmge Kitabevi.

Poyraz. B. (2002). Haber ve Haber Programlarında İdeoloji ve Gerçeklik. Ankara: Ütopya Yayınevi.

Potter, J. (1986). Perceived reality in the cultivation hypothesis. Journal of Broadcating, (30): 159174

Potter, J. (2005) Media Literacy. Third Edition. CA: Sage Publications.

Sanders, B. (1999). Öküzün A'st- Elektronik Çağda Yazılı Kültürün Çöküşü ve Şiddetin Yükselişi, (Çeviren: Şehnaz, T.), Ankara: Ayrıntı Yayınları.

Saydam, A. (2012). Illetişimin Akıl ve Gönül Penceresi Alg̨lama Yönetimi. İstanbul: Remzi Yayınları. Saydam, A. (2014). Algılama Yönetimi. (6. bs.). İstanbul: Remzi Kitabevi.

Şahin, Ç. ve Tüzel S. (2011). Medya Dünyasının Gerçek Dünyayı Yansıtma Düzeyinin Öğretmen Adaylarının Görüşleri Doğrultusunda Belirlenmesi. Eğitim ve Bilim Dergisi, 36 (159): 127-140.

Taşkıran, N.Ö. (2007). Medya Okuryazarlı̆̆ına Giriş. İstanbul: Beta Basım Yayın

Toylor, S. E and Howell R. J. (1973). The ability of three-four and five year -old to distinguish fantasy from reality. Journal of Genereic Psychology, (122): 315-318.

Tutar, H. (1988). Simetrik ve Asimetrik İletişim Bağlamanda Örgütsel Algılama Yönetimi. Ankara: Seçkin Yayıncilık.

Türk, M.S. (2014). Medyanın Gerçeklik İnşası ve Gerçeklik Algısı. Türkiz Siyaset ve Kültür Dergisi, 5(28): 9-33. 
Tyner, K. (1993). Media Literacy in a Digital Age. Mahwah, NJ: Erlbaum.

Uğurlu, Ö. (2015). Gerçek Olanın İkame Alanı Olarak Twitter: Online Dünyada Yönetilen Algılar. (Editör: Karakulakoğlu, S.Ö ve Uğurlu, Ö.), İletişim Çalışmalarında Digital Yaklaşımlar içinde (s.295307). Ankara: Heretik Yayınları.

Uysal, M. (2006). Medya ve Şiddet. Toplumsal Bir Sorun Olarak Şiddet Sempozyumu. 20-21 Mayıs Ankara: 121-129.

Ünüvar, N. (2013). Dijital Siyaset. İstanbul: Pozitif Yayıncllık.

Van der Voorti T. H. A. (1986). Television Violence: A Child's View. Amsterdam: North Holland.

Wright, J. C, Huston, A. C., Reitz A. L. and Piemyat, S. (1994). Young Children's Perceptions of Television reality: Determinants and Developmental Differences. Development Psychology, (30): 229-239.

Yazgan, A., Deniz, R. ve Kıncal (2009). Eğitim Fakültesi Öğrencilerinin Medya Okuryazarlık Düzeyleri, Demokrasi Algıları ve Dogmatik Düşünce Becerileri Arasındaki İlişkinin İncelenmesi. International Symposium on Democracy And Democracy Education in Europe. 11-12 Haziran 2009: 516530 Çanakkale.

Yeniçıktı, N.F. (2014). İletişimsel Eylem ve Facebook: Gezi Parkı Olaylarında Sosyal Medyanın Gücü. Selçuk Üniversitesi İletişim Fakültesi Dergisi, 8 (2): 263-284. 